\title{
Stenting in Coarctation of the Aorta
}

\author{
SYED ALI AHSAN ${ }^{1}$, SYED SAWKAT HOSSAIN ${ }^{2}$, MD. SAIFULLAH PATWARY ${ }^{1}$, MD. ABU SALIM ${ }^{1}$, AYESHA \\ RAFIQUE CHOWDHURY ${ }^{1}$, KMHS SIRAJUL HAQUE ${ }^{1}$ \\ ${ }^{1}$ Department of Cardiology, BSMMU, Dhaka; ${ }^{2}$ Port Huron Vascular Clinic, PC, Michigan, USA.
}

Address for correspondence: Dr. Syed Ali Ahsan, Associate Professor, Interventional Cardiology, Bangabandhu Sheikh Mujib Medical University, Dhaka. e-mail: draliahsan@yahoo.com

\begin{abstract}
:
Narrowing of the aorta most commonly occurs in the region where the ductus arteriosus joins the aorta, i.e. at the isthmus just below the origin of the left subclavian artery. It is associated with other abnormalities, of which the most frequent are bicuspid aortic valve and 'berry' aneurysms of the cerebral circulation. Acquired coarctation of the aorta is rare but may follow trauma or occur as a complication of a progressive arteritis, Takayasu's disease.

A 21 years old young lady noted intermittent headache and occasionally weakness or cramps in the legs on walking from her early childhood. On examination her blood pressure in the upper limb 210 / $120 \mathrm{~mm} \mathrm{Hg}$, in lower limb was $100 / 60 \mathrm{~mm} \mathrm{Hg}$. There was radio-femoral delay and femoral pulse was weak. A systolic murmur is heard posteriorly. Radiological examination showed changes in the contour of the aorta and rib notching. ECG shows left ventricular hypertrophy. Echocardiography showed only concentric hypertrophy of LV. CT angiogram revealed coarctation of the aorta present with development of collaterals. Inspite of getting 3 different antihypertensive drugs her BP was uncontrolled. In our hospital her coarctation of the aorta was corrected by by endovascular stenting on the coarctation of the aorta. 5F, 7F \& then 9F sheath, straight \& $J$ tiped terumo \& $J$ tip taflon coated $300 \mathrm{~cm}$ long wire was used. Predilatation was done by ballon used $3 \times 10 \mathrm{~mm}$ over 0.34" J tip terumowire @ 10 atm. Post dilatation was done by ballon used 7x20 mm @ 4 atm. Wall stent (Endoprosthesis) $9 F$ was used. $1^{\text {st }}$ Wall stent $14 \mathrm{~mm} \times 40 \mathrm{~mm}$ self expanding and $2^{\text {nd }}$ Wall stent $16 \mathrm{~mm} \times 60 \mathrm{~mm}$, upper part covered the mouth of left subclavian artery. Result of stenting was good and procedure was uneventful.
\end{abstract}

\section{Introduction:}

Narrowing of the aorta most commonly occurs in the region where the ductus arteriosus joins the aorta, i.e. at the isthmus just below the origin of the left subclavian artery. $^{1}$

The condition is twice as common in males as in females and occurs in 1 in 4000 children. It is associated with other abnormalities, of which the most frequent are bicuspid aortic valve and 'berry' aneurysms of the cerebral circulation.

Acquired coarctation of the aorta is rare but may follow trauma or occur as a complication of a progressive arteritis, Takayasu's disease. ${ }^{1-6}$

\section{Case report :}

A 21 years old young lady noted headache from her early childhood and occasionally weakness or cramps in the legs on walking. On examination the blood pressure is raised in the upper body 210 / 120 mm Hg but low 100 / 60 $\mathrm{mm} \mathrm{Hg}$ in the legs. The femoral pulses are weak, and delayed in comparison with the radial pulse. A systolic murmur is heard posteriorly.

Radiological examination show changes in the contour of the aorta and notching of the under surfaces of the ribs from collaterals. The ECG show left ventricular hypertrophy.

CT angiogram show coarctation of the aorta present with development of collaterals.

Patients was managed by endovascular stenting on the coarctation of the aorta (Fig.-1). Measuring tape was paste over patients chest. 5F, 7F \& then 9F sheath was used. Straight \& J tiped terumo \& J tip Taflon coated $300 \mathrm{~cm}$ long wire was used. Predilatation was done by ballon used 3x10 mm over 0.34" J tip terumo wire@ 10 atm. Post dilatation was done by ballon used 7x20 mm @ 4 atm. Wall stent (Endoprosthesis) $9 \mathrm{~F}$ was used. $1^{\text {st }}$ Wall stent $14 \mathrm{~mm} \mathrm{x}$ $40 \mathrm{~mm}$ self expanding and $2^{\text {nd }}$ Wall stent $16 \mathrm{~mm}$ x $60 \mathrm{~mm}$, upper part covered the mouth of left subclavian artery. Result of stenting was good. 

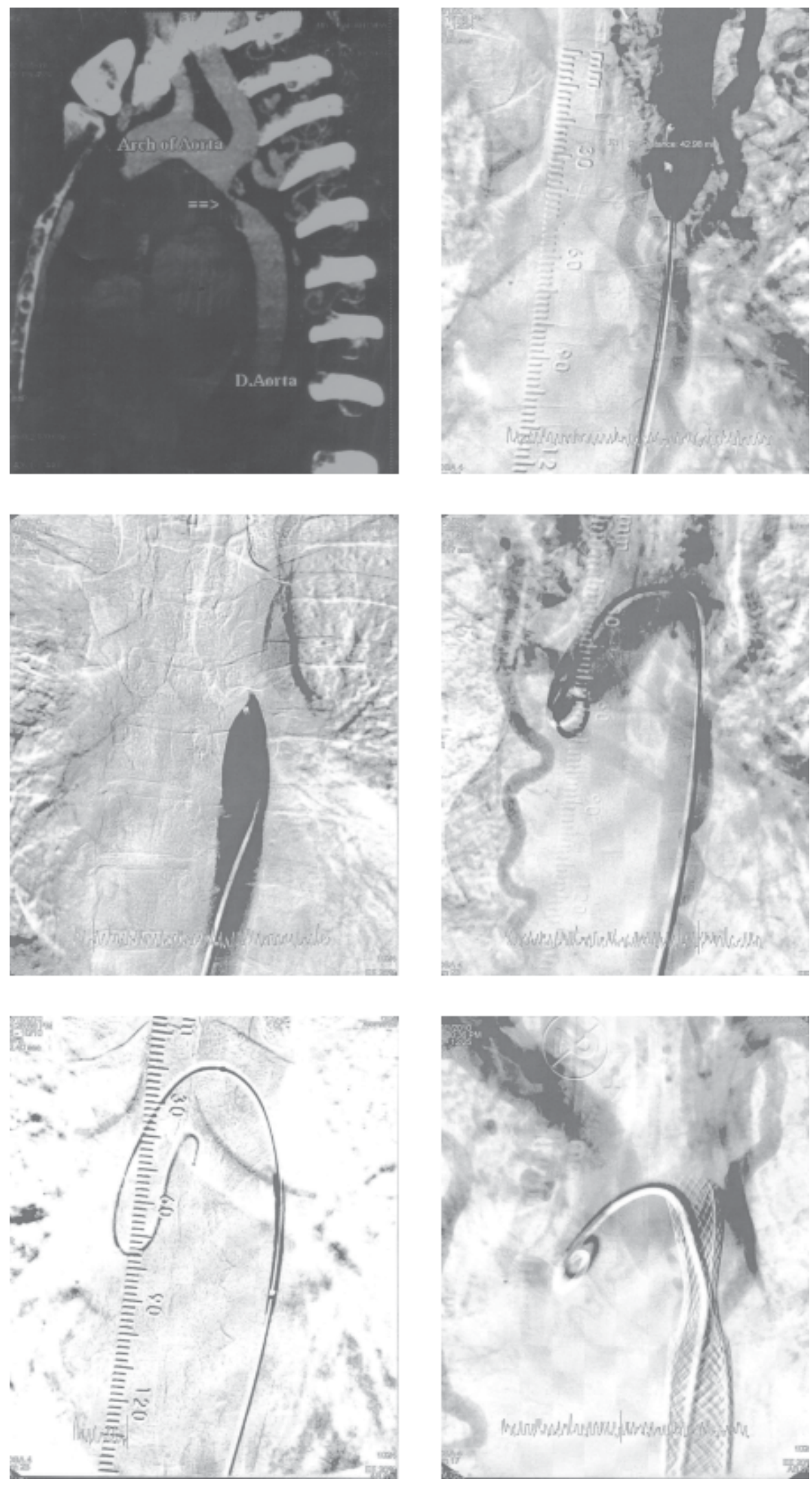

Fig.-1: Aortgrams from a coarctation of the aorta before and after stent implantation. Initial implantation of endovascular stenting in a 21 years old patients with native coarctation of the aorta. 


\section{Discussion:}

Coarctation of the aorta (CoA) in adolescents and adults can be managed in different ways depending upon the age of presentation, coarctation morphology, whether native or a recurrence following surgery/angioplasty and the local institutional expertise. In the last decade, stenting has been performed in this age group as an alternative to balloon angioplasty and surgery with good intermediate term results. ${ }^{7-25}$

The rationale for stent implantation is that over dilation of the coarctation segment are unnecessary, thus avoiding major transmural tears, while at the same time the stent struts will splint any smaller tears against the aortic wall preventing progressive dissection and aneurysm formation. ${ }^{13,20,21,23}$ The acute elastic recoil of the coarctation segment that contributes to a suboptimal initial result and later recoarctation by ballooning alone is prevented by stent implantation. The risk of aneurysm formation, dissection, aortic rupture and death, however, has not been eliminated. ${ }^{15,18}$ Excessive stretching of a tight coarctation, however, could still lead to aneurysm formation and rupture so graded dilation, allowing for healing before further dilation $8,11-15,23,24$. The disadvantages of stenting an aortic wall is that it may alter wall compliance, pressure wave propagation and blood pressure. In young patients additional dilatations will be required to keep pace with growth. Neointimal growth causing mild restenosis may also need additional dilatations. ${ }^{8-10,13-15,17,27}$

The most commonly used stent is the balloon dilatable type which allows for further expansion of the stent as child grows or if further dilatation is needed in a critical lesion. Availability of Wall Stents may decrease all these complications and has a special place in developing countries where cost is an important issue and one off treatment may have to be offered. ${ }^{16,28-35}$

Our results add to the current limited knowledge about Wall Stents and these may be used as the therapy of choice in adolescents and adults with native coarctation of the aorta with severe and complex coarctation of aorta. In conclusion, in selected patients with coarctation of the aorta stent implantation is feasible and short and mid term follow up is encouraging. A small incidence of aneurysm formation is inevitable in all forms of treatment. Most procedure related complications can be treated with Wall Stents (Endoprosthesis). Wall Stents may become treatment of choice in adolescents and adults. Long term follow up is needed to address the complications and disadvantages.

\section{References:}

1 Bobby JJ, Emami JM, Farmer RDT, et al. Operative survival and 40 year follow up of surgical repair of aortic coarctation. Br Heart j 1991; 65: 271-76.

2 Malan JE, Benatar A, Levin SE. Long-term follow-up of coarctanon of the aorta repaired by patch angioplasty. Int $J$ cardiol 1991; 30: 23-32.

3 Kappetein PA, Guit GL, Bogers JJC, et al. Noninvasive longterm follow-up after coarctation repair. Ann Thorac Surg 1993; 55:1153-59.

4 Stewart AB, Ahmed R, Travill CM, et al. Coarctation of the aorta life and health 20-44 years after surgical repair. $\mathrm{Br}$ Heart $J$ 1993; 69: 65-70.

5 Kimball TR, Reynolds JM, Mays WA, et al. Persistent hyperdynamic cardiovascular state at rest and during exer-cise in children after successful repair of coarcration of the aorta. J Am Coll Cardiol 1994; 24: 194-200.

6 Zehr KJ, Gillinov AM, Redmond JM, et al. Repair of coarc-tation of the aorta in neonates and infants: a thirtyyear experience. Ann Thorac Surg I 995; 59: 33-41.

7 Lababidi ZA, Daskalopoulos DA, Stoeckle H. Transluminal balloon coarctation angioplastv; experience with 27 pa-tients. Am J Cardiol 1984; 54: 1288-91.

8 Beckman RH, Rocchini AP, Dick M, et al. Percutaneous balloon angioplasty for native coarctation of the aorta. $J$ Am Coll Cordiol 1987; 10: 1078-84.

9 Cooper RS, Ritter SB, Rothe WB, et al. Angioplasty for coarctstion of the aorta: long-term results. Circulation 1987; 75: $600-04$.

10 Wren C, Pcart I, Bain H, et al. Balloon dilation of unoperated aortic coarctation: immediate results and one year follow-up. Br Heart J 1987; 58: 369-73.

11 Morrow WR, Vick GW, Nihill MR, et al. Balloon dilation of unoperated coarctation of the aorta: short- and intermediateterm results. J Am Coll Cardiol 1988; 11: 133-38

12 Tvnan M, Finley JP, Fontes V, et al. Balloon angioplasty for the treatment of native coarctation: results of valvuloplastv and angioplasty of congenital anomalies registry -ments. Am J Cordiol 1990; 65: 790-92.

13 Fawzv ME, Dunn B, Galal O, et al. Balloon cosrctation angioplasry in adolescents and adults: early and intermedi-ate results. Am Heart Y 1992; 124: 167-71.

14 Tyagi S, Arora R, Kaul UA, et al. Balloon angioplasty of native coarctation of the aorta in adolescents and young adults. Am Heart J 1992; 123: 674-80.

15 Fletcher SE, Nihill MR, Grifka RG, et al. Balloon angioplasty of native coarctation of the aorta: midterm follow-up and prognostic factors. J Am Coll Cardiol 1995; 25: 730-34.

16 Ovaert C, Benson UN, Nykanen D, et al. Transcatheter treatment of coarctation of the aorta: a review. Pediatr Cardiol 1998; 19: 27-44.

17 Fawzy ME, Sivanandam V, Galal O, et al. One- to ten-year follow-up results of balloon angioplasty of native coarcta-tion 
of the aorta in adolescents and adults. J Am Coll Car-diol 1997; 30: 1542-46.

18 Schrader R, Bussmann WD, Jacobi V, et al. Long-term effects of balloon coarctation angioplasty on arterial blood pressure in adolescent and adult patients. Cathet Cardiovasc Diagn 1995; 36: 220-25.

19 Phadke K, Dyet JF, Aber CP, et al. Balloon angioplastv of adult aortic coarctation. Br Heart J 1993; 69: 36-40.

20 Kulick DL, Kotlewski A, Hurvitz RJ, et al. Aortic rupture following percutaneous catheter balloon coarctoplasty in an adult. Am Heart $j$ 1990; 119: 190-93.

21 Rico J, Sobrino N, Calvo L, et al. Angioplastia translumina percutanea en Ia coartacion aortica del adulto joven. Rev Esp Cardiol 1989; 42: 415-17.

22 Attia IM, Lababidi ZA. Early results of balloon angioplasty of native aortic coarctation in young adults. Am J Cardiol 1988; 61: $930-31$.

23 Biswas PK, Mitra K, Dc 5, et al. Follow-up results of balloon angioplasty for native coarctation of aorta. Indian Heart $J$ 1996; 48: 673-76.

24 Kale PA, Lokhandwala YY, Kulkarni HL, et al. Balloon angioplasty for native aortic coarctation. Indian Heart $J$ 1992; 44: 207-11.

25 Ray DG, Subramanyan R, Titus T, et al. Balloon angioplasty for native coarctation of the sorts in children and adults: factors determining the outcome Int J Cardiol 1992; 36: 273-81.

26 Suarez de Lezo J, Sancho M, Pan M, et al. Angioplasty followup after balloon angioplasty for coarctation of the aorta. $J$ Am Coll Cardiol 1989; 13: 689-95.
27 Syamasundar P, Thapar MK, Kutayli F, et al. Causes of recoarctation after balloon angioplasty of unoperated aortic coarctation. J Am Coll Cardiol 1989; 13: 109-15.

28 Suarez de Lezo J, Pan M, Romero M, et al. Balloon-expandable stent repair of severe coarctation of aorta. Am Heart J 1995; 129: 10028.

29 Rosenthal E, Qureshi SA, Tynan M. Stent implantation for sonic recoarctation. Am Heart J 1995; 129: 1220-21.

30 Bulbul ZR, Bruckheimer E, Love JC, et al. Implantation of balloon-expndable stents for coarctation of the aorta: Implantation data and short-term results. Cathet Cardiovasc Diagn 1996; 39: 36-42.

31 Ebeid MR, Prieto L.R, Latson LA. Use of balloon-expandable stents for coarctation of the aorta: initial results and intermediate- term follow-up. J Am Coll Cardlol 1997; 30: 1847-52.

32 Ledesma M, Diaz Y Diaz E, Alva Espinosa C, et al. Stents en coartacion aortica. Resultados inmediatos. Arch Inst Cardiol Mex 1997; 67: 399-404.

33 Pedulla DM, Grifita RG, Mullins CE, et al. Endovacular stent implantation for severe recoarctation of the aorta: case report with angiographic and 18-month clinical follow-up. Cathet Cardiovasc Diagn 1997; 40: 311-14.

34 Diethrich EB, Heuser RR, Cardenas JR, et al. Endovascular techniques in adult aortic coarctation: the use of stents for native and recurrent coarctation repair. J Endovasc Surg1995; 2: $183-88$.

35 Magee AG, Brrezinska-Rajszys G, Qureshi SA, et al. Stent implantation for sonic coarctation and recoarctation. Heart 1999; 82: 600-06.

36 O’Laughlin MP, Slack MC, Griflca RG, et al. Implantation and intermediate-term follow-up of stents in congenital heart disease. Circulation 1993; 88: 605-14. 